\title{
Diskursus Pemikiran Al-Jahiz Mengenai Gangguan Berbahasa
}

\author{
M. Azizzullah Ilyas \\ Institut Agama Islam Negeri Curup \\ alcurufi@gmail.com
}

\begin{abstract}
The study of language pathology has been going on longer and developing with the development of language studies, the problems encountered in learning speaking skills are often related to speech skills which sometimes enter the language pathology area which requires educator knowledge especially the interference of Arabic learners. This study aims to analyze speech problems and language in the classical study represented by Al-Jahiz seen through the perspective of modern linguistics. This study uses a qualitative approach with library data sources, descriptive analysis is done by reading the content and analyzed. The results showed that Al-Jahiz's views were divided into speech disorders and language disorders; lusghah, luknah, lahn and ayy. Jahiz saw lahn as the worst speech disorder, and he assumed that in lahn is not only caused by articulation factors and motor aphasia but can also be driven by personal factors to replace sounds that are difficult to pronounce with light sounds.
\end{abstract}

Keywords: Al-Jahiz, speech disorder

\begin{abstract}
Abstrak
Studi mengenai gangguan berbahasa telah berlangsung lebih lama dan berkembang bersama berkembangnya studi bahasa, permasalahan yang dihadapi dalam pembelajaran keterampilan berbicara sering berkaitan dengan kemampuan wicara yang terkadang masuk ke wilayah gangguan berbahasa yang memerlukan pengetahuan pendidik terkhusus gangguan pada pembelajar bahasa Arab. Penelitian ini bertujuan menganalisa pemikiran mengenai problematika wicara dalam kajian linguistik Arab klasik yang diwakili Al-Jahiz dan disorot lewat pendekatan linguistik modern. Kajian ini menggunakan pendekatan kualitatif dengan sumber data kepustakaan, analisa deskriptif dilakukan dengan pembacaan konten dan dianalisa. Hasil penelitian menunjukan bahwa pandangan dan pemikiran Al-Jahiz lebih kepada bentuk gangguan berbahasa; lusghah, luknah, lahn dan ayy. Al-Jahiz melihat lahn sebagai gangguan terburuk, dan menurutnya gangguan berbahasa tidak
\end{abstract}


hanya disebabkan oleh faktor artikulator dan afasia motorik tetapi dapat juga didorong oleh faktor personal untuk mengganti bunyi yang terasa sulit diucapkan dengan bunyi yang lebih ringan.

Kata Kunci: Al-Jahiz, Gangguan Berbahasa.

\section{Pendahuluan}

Sering ditemukan beberapa kasus pelajar bahasa yang tidak dapat menuturkan beberapa bunyi, ataupun mereka menuturkan huruf dan kalimat dengan cara yang tidak tepat. Kebanyakan kasus dalam kesulitan berbicara menimbulkan banyak persoalan ketika mereka mencoba berkomunikasi, hingga memunculkan rasa rendah diri. Persoalan ini sesungguhnya bukanlah persoalan biasa tetapi merupakan penyakit yang dapat bersumber dari berbagai faktor beragam yang memerlukan penanganan khusus untuk mengatasinya.

Setiap orang menginginkan memiliki kemampuan dalam berbahasa dengan baik, baik pada bahasa pertama maupun bahasa asing yang dipelajarinya, metode untuk mendukung kemampuan berbicara dan pengembangan bahasa merupakan hal yang sangat kompleks. Namun dalam beberapa keadaan terjadi beragam kesulitan dalam menuturkan suatu bunyi atau berbicara dalam bahasa tertentu yang ternyata berkaitan dengan gangguan berbicara ataupun berbahasa yang tidak dialami sebelumnya dalam bahasa ibu secara signifikan namun tampak saat mempelajari bahasa asing.

Kelainan, penyakit atau gangguan sering diistilahkan dengan patologi, dan ilmu yang mengkaji bagaimana mengatasi gangguan dalam berbicara dan mempelajari, menganalisa serta menemukan metode untuk mengatasi gangguan tersebut sering disebut dengan patologi bahasa. Terdapat beberapa defenisi yang menjelaskan tentang kata patologi, dalam KBBI kata patologi bermakna ilmu tentang penyakit, namun ketika dikaitkan dengan kata bahasa menjadi patologi bahasa bermakna Penyelidikan mengenai cacat dan gangguan yang menghambat kemampuan berkomunikasi verbal manusia. ${ }^{1}$

Studi mengenai patologi bahasa telah berlangsung lama, kajian problematika dalam berbicara telah dimulai sejak 2000 tahun yang lalu namun hingga kini belum menunjukan perkembangan yang berarti, kecuali hanya beberapa kemajuan dalam mengatasi kesulitan berbicara. Hingga abad ke 19 dan 20 kajian patologi hanya berfokus pada problematika berbicara. Mengatasi kesulitan dalam berbicara berfokus dalam mengatasi kesulitan dalam menuturkan huruf dan berbicara serta persoalannya baik pada anak-anak ataupun orang dewasa yang menghadapi persoalan dalam berkomunikasi.

\footnotetext{
1 Tim Pusat Bahasa, Kamus Besar Bahasa Indonesia,(Jakarta: Pusat Bahasa, 2008), hal.
} 1030. 
Ketidakmampuan dalam berkomunikasi yang disebabkan oleh kelainan dalam sistem dan ketidakseimbangan menjadi tanda bahwa pribadi orang tersebut tidak terorganisasi dengan baik dalam lingkungannya, keluar dari perubahan harmoni sosial. Keadaan tersebut menjadikan persolan seseorang yang berada dalam lingkup patologi bahasa dan berada dalam fenomena kajian ilmu pengetahuan. ${ }^{2}$

Secara umum terdapat dua permasalahan dalam berbicara, kelainan yang terdapat pada alat wicara yang menyebabkan orang tersebut terganggu dalam memproduksi bahasa, dan gangguan berbahasa. Kemampuan berbicara merupakan kemampuan seseorang untuk menuturkan suatu bunyi atau huruf dan kelainan dalam bidang ini diistilahkan dengan gangguan berbicara (speech disorder), sedangkan kemampuan untuk menyampaikan ide dalam bentuk bahasa diistilahkan dengan kemampuan berbahasa dan mereka yang memiliki persoalan dalam berbahasa dapat mengalami gangguan berbahasa (language disorder).

Gangguan berbicara dapat dilihat pada beberapa kasus, seperti tidak mampu membunyikan suatu kalimat atau huruf dengan jelas, serak dan gagap. Gangguan berbicara dapat pula diistilahkan dengan gangguan artikulasi dan fonologi. Gangguan artikulasi dapat diklasifikasikan berdasar gangguan pada organ. Artikulasi dianggap berfungsi dengan baik ketika tidak ada patologi yang diketahui yang menyebabkan terjadinya kesalahan. Mereka yang memiliki gangguan fungsi artikulasi menunjukkan kesalahan produksi ucapandengan tidak adanya etiologi yang dapat diidentifikasi. Memiliki ketajaman pendengaran yang memadai dan kemampuan intelektual tanpa tanda-tanda kelainan struktural yang signifikan atau disfungsi neurologis. Gangguan organik dihasilkan dari penyebab fisik yang diketahui, seperti gangguan pada celah langit-langit,disfungsi neurologis, atau gangguan pendengaran. Beberapa anak mungkin memiliki gangguan berbicarabaik defisit fungsi alat artikulasi ataupun gangguan organ. ${ }^{3}$

Gangguan bahasa dapat juga didefinisikan sebagai pemerolehan terhadap bahasa yang terjadi secara abnormal, baik pada pemahaman atau penggunaan bahasa lisan atau tulisan. Gangguan ini mencakup kemampuan bahasa reseptif dan ekspresif. Gangguan ini mungkin juga melibatkan aspek apa pun dari bentuk, konten, atau penggunaan komponen dari sistem linguistik. ${ }^{4} \mathrm{G} a n g g u a n$ berbahasa dapat melibatkan pemahaman dan produksi bahasa. Bahasa pemahaman (bahasa reseptif) mengacu pada kemampuan untuk memperoleh makna dari pesan-pesan auditori atau visual yang masuk. Sedangkan produksi bahasa (bahasa ekspresif) melibatkan kombinasi simbol linguistik untuk

${ }^{2}$ J.R. Kantor,Human Personality and Its Pathology, The Journal of Philosophy, Psychology and Scientific Methods, Vol. 16, No. 9 (Apr.24, 1919), hal.236.

${ }_{3}^{3}$ P. Roth Froma, Collen, Worthington. Treatment Resource Manual (For Speech Language Patology), (USA: Delmar, 2011), hal. 102.

${ }^{4}$ Ibid., hal. 150 
membentuk pesan yang bermakna. Gangguan bahasa umumnya diklasifikasikan menurut komponen utama sistem linguistik: Fonologi, morfologi, sintaksis, semantik, dan pragmatik. Gangguan berbahasa dapat juga dilihat pada kurangnya kemampuan dalam memahami pembicaraan orang lain, ketidakmampuan dalam membaca, berbicara dan menulis.

Terdapat beragam upaya yang dilakukan untuk mengatasi persoalan baik pada tataran gangguan berbicara dan gangguan berbahasa, upaya tersebut diklasifikasikan berdasarkan gangguan yang dialami. Dalam mengatasi gangguan berbicara pendekatan yang dilakukan dengan mengatasai dua gangguan utama yakni gangguan pada fungsi dan gangguan pada organ.Sedangkan bentuk gangguan berbahasa yang terjadi pada anak-anak dapat berbentuk keterlambatan perkembangan berbicara maupun gangguan perkembangan bahasa. ${ }^{5}$

Pengetahuan akan speech disorder dan language disorder dapat digunakan sebagai sarana kolaborasi dalam upaya pendidik menemukan metode yang tepat untuk mendukung pembelajaran bagi mereka yang mengalami gangguan dalam menuturkan kosakata tertentu dalam bahasa tertentu. Karena untuk memastikan bahwa mereka yang memiliki kesulitan dalam pembelajaran wicara mencapai hasil belajar positif, pendidik perlu mengetahui ciri-ciri gangguan tampak pada seseorang hingga dapat dikelompokkan kedalam kelas khusus untuk mendapatkan model pembelajaran yang berbeda dari mereka yang tidak mengalami gangguan kesulitan. Pengetahuan ini juga penting pagi pendidik dalam memberikan penilaian yang berbeda bagi peserta didik dengan gangguan wicara.

Selain hal tersebut, memberikan informasi kepada mahasiswa mengenai hal ini juga termasuk hal penting, pendidik yang mengampuh subjek yang berkaitan dengan metodologi pembelajaran bahasa perlu memperkenalkan kepada mahasiswa silabus khusus pra-pembelajaran bagi mereka yang memiliki gangguan berbicara ataupun gangguan berbahasa. Pada Mahasiswa juga dapat diperkenalkan dengan menggunakan metode pengajaran berbasis kelas. ${ }^{6}$ Adapun diantara tanggung jawab sekolah adalah mengetahui kesulitan siswa berbicara dalam suatu bahasa yang dipelajarinya, dan mengetahui sebab penyimpangan siswa dalam menuturkan suatu bunyi.

Kajian bahasa Arab juga telah membicarakan mengenai gangguan dalam berbahasa, yakni bahasa yang keluar dari batasan-batasan bahasa Arab fushah.

${ }^{5}$ Verhoeven, Balkom. Classification of developmental language disorders : theoretical issues and clinical implications, (New Jersey: Lawrence Erlbaum Associates, Inc. 2004), hal. 3.

${ }_{6}$ Miolo, G, Devora, S. Speech Language Pathology and Education Students Engage in Interprofessional Collaborative Practice to Support Children with Special Needs in Preschool Settings. Journal of Interprofessional Education \& Practice. Vol. 4 (2016)., hal. 81

7 Umar, Ahmad Mukhtar,Dirasat Sautiyah wa Ta'limal-Lughah Arabiyah lil Ajanib,(Madinah: Maktabah Arabiyah, 1401), hal. 88. 
Fushah merupakan perkataan yang benar dan jelas dalam makhraj dan sifat, artikulasi, patch dan intonasi, penggalan yang memiliki makna, perkataan yang sempurna, memiliki karakteristik sempurna, dan memiliki ciri sebagai media yang efektif, dapat dipahami, baik secara lisan ataupun tulisan, memliki pola mengikat, dan dipraktekkan dalam bahasa Arab sejak era permulaan, sejak awal munculnya Islam pada Abad ke-6 M, dan jarang terdapat tulisan yang keluar dari gaya ini kecuali sedikit. Penamaan yang terkenal untuk bahasa ini adalah bahasa fushah. ${ }^{8}$

Kajian mengenai speech disorder dan language disorder serta batasan untuk menentukan seseorang mengalami gangguan tersebut perlu lebih diperjelas. Pandangan al-Jahiz yang merupakan pandangan tokoh bahasa klasik dapat dijadikan pembanding dalam persoalan ini. Dalam penelitian berbahasa Arab, Aisyah Muhammad Utsman menjelaskan bahwa al-Jahiz memiliki pandangan dalam bidang phonologi, namun Aisyah tidak mengkaji persoalan gangguan berbahasa secara spesifik, kajiannya lebih berfokus pada aspek fonetik. Menurutnya al-Jahiz telah memberikan pemikiran mengenai fungsi lisan dalam produksi ujaran, hubungan gusi dan lidah, dan cacat lisan dalam produksi ujaran, huruf yang asing dan kesulitan dalam menuturkan huruf-huruf tertentu. ${ }^{9}$

Terdapat beberapa istilah yang digunakan dalam menjelaskan mengenai persoalan dalam berbahasa, yang paling sering adalah cacat wicara, gangguan wicara, dan patologi bahasa. Dalam beberapa kajian sering terjadi kekeliruan untuk menggabungkan antara cacat dan gangguan berbahasa. Untuk memperjelas persoalan ini perlu diketahui batasan-batasan mengenai hal ini. Dalam hal ini cacat berbahasa dapat dimaknai persoalan yang dihadapi seseorang dalam memproduksi bahasa verbal yang lebih disebabkan oleh fungsi artikulator yang kurang sempurna. Sedangkan gangguan berbahasa merupakan persoalan dan kekeliruan penutur verbal yang disebabkan oleh faktor-faktor instrinsik ataupun ekstrinsik yang bukan berkaitan dengan fungsi artikulator.

Al-Jahiz dalam hal ini menggunakan istial "uyub" yang merupakan jamak dari kata "aib". Makna aib menurut Kamus Besar Bahasa Indonesia adalah cela; noda; salah; keliru. Sedangkan dalam Mu’jam al Ghani bermakna kekurangan, dalam Mu'jam Ra'id bermakna suatu kekurangan pada seseorang yang membuatnya cacat dan malu. ${ }^{10}$

Pembahasan mengenai cacat wicara al-Jahiz dibahas lebih oleh Rahim Jum'ah dalam Dars Shaut wa Sharf inda Jahiz. Namun dalam tulisan tersebut lebih mendeskripsikan pemikiran al-Jahiz dari apa yang tertuang dalam karya-

\footnotetext{
8 Aqtas, Abdul hamid. Haula Hakikat Fushah. Jurnal Saqafiyah. Vo. 5 (2007) hal. 64

9 Aisyah, Muhammad Utsman, Dauru Jahiz fi Darsi Sauthi Arabi, Jurnal Dirasat Ulum Insaniyah wa Islamiyah, Vol. 2 (2016), hal. 841

${ }^{10}$ Mas'ud, J. Ar-Ra'id Mujam Lughawi Ashri,(Beirut: Darul Ilmi Lil Alamin, 1992), hal. 476.
} 
karyanya, kajian dalam fonologi, nahwu dan morfologi. Jum'ah tidak mengkaji pengembangan dan analisa terhadap pandangan al-Jahiz dalam bungkai kajian linguistik bahasa modern. ${ }^{11}$

Kajian lain dilakukan oleh Fauzi Ibrahim dengan judul Ushul Intaj Khitab Baligh inda Abi Utsman al-Jahir, dalam kajian tersebut mengungkapkan pandangan-pandangan al-Jahiz dalam bidang Balaghah, hampir mirip dengan kajian sebelumnya Ibrahim lebih mendeskripsikan isi dari kitab al-Bayan wa Tabyin, mendekati resume yang dapat simpulkan dari hasil bahasan yang dituliskan dalam abstrak.

Sedangkan penelitian ini lebih dalam memperjelas pandangan dan pemikiran al-Jahiz mengenai gangguan wicara ataupun gangguan berbahasa yang selanjutnya mengkaji pemikiran tersebut dilihat dari sudut pandang linguistik modern dan terakhir, relevansi dan manfaat pemikiran Al-Jahiz dalam menunjang pembelajaran bahasa. Penelitian ini merupakan studi literatur yang mengkaji dan menganalisa sumber-sumber utama kepustakaan dan yang berkaitan.

\section{Pembahasan}

\section{Biografi al-Jahiz}

Nama asli al-Jahiz adalah Abu Utsman Amru bin Bahr bin Mahbub alKitani al-Alaisi yang dikenal dengan al-Jahiz al-Bisri. Keluarganya berasal dari kabilah Arab Kinanah dari kalangan Madariyah. ${ }^{12}$ Al-Jahiz dilahirkan di Basrah tahun $159 \mathrm{H}$ dan meninggal tahun $255 \mathrm{H}$ dimasa Khalifah al-Muhtadi Billah. Ia tinggal bersama ibunya yang bekerja sebagai pedagang makanan. Al-Jahiz muda mendapatkan pengetahuan dari belajar secara langsung kepada pada para cendikiawan terkadang di masjid Basrah yang merupakan pusat majelis-majelis ilmu, diantaranya majelis Hasan al-Bashri dan Washil bin Atha' dan terkadang dari pasar Marbad yang dikenal pada masa itu sebagai lokasi para ahli sya'ir dan ahli bahasa baik dari Madhar ataupun dari Arab Badui berkumpul.

Al-Jahiz mengambil ilmu dari para sarjana dan cendikiawan seperti Abu Ubaidah Ma'mar at-Timi, darinya Jahiz mempelajari bahasa, ilmu alam dan sya'ir. Ia juga belajar dari Abu Sa'id al-Asmu'i, dan darinya al-Jahiz mempelajari pengetahuan umum, sejarah, dan peringatan-peringatan, pengetahuan dalam bidang zoologi, pengobatan dan morfologi. Ia juga belajar dari Ibnu I'rabi, Abu Amru Ishak as-Syaibani seorang ahli dalam bidang Hadis, juga Abu Zaid Said alAnshari. ${ }^{13}$ 2 (2008).

${ }^{11}$ Jum'ah, Rahim,Dars Shauti wa Sharfi inda Jabiz: Jurnal Kuliyah Tarbiyah Asasiyah. Vol.

12 Murtadha, Ibnu,Tabaqat Mu'tazilah,(Beirut: Maktabah Katulikiyah, 1961), hal. 67.

${ }^{13}$ Hamawi, Yakut,Mu'jam Adabi Juz 12,(Kairo: Maktabah Hindiyah, 1926), hal. 39. 
Al-Jahiz merupakan seorang ilmuan yang produktif dalam menghasilkan karya-karya tulis, ia menulis kurang lebih 200 buku dan diantara karya-karyanya yang direkam sejarah adalah kitab al-Bayan wa Tabyin, az-Zar'u wa Nakbl, al-Farq bayna al-Nabii wal Mutanabiy, Al-Ma'rifa, kitab jawabat, kitab masail. kitab al-Rad ila Ashab al-A'lam, Nazam al-Qur'an, Tsalas Nash, Masa'il fi Qur'an, Fadilah alMu'tarilah, Al-Radd ila Musyabahah, al-Imamah ala Mazhab syi'ah, Hikayat Qaul Ashnaf Zaidiyah, Utsmani, Akbbar wa Kaifa Tasib, Radd ala an-Nashara, Radd ala Utsmaniyah, Imamah Mu'awiyah, Imamah Bani Abbas, Kitab Kiyan, Kitab Kawad, Kitab al-Lisus, Kitab ar-Zikeru baina Zaidiyah wa Rafidah, Mukhatabah fi Taubid, Sina'atul Kalam, Taswib Ali fi Tabkim Hakimain, Wujubul Imamah, Kitab Asnam, al-Wukala' al-Muwakilain, Kitab Syarib wa Mashrub, Iftikhar Syita wa Saif, Kitab Mu'alimain, Kitab al-Jawari, Kitab Nawadir al-Hasan, Kitab Bukbala', Kitab Farq, Kitab Arshan da Barsan, Fakbru Kabtani wa Adbnani, Kitab Tarbi' wa Tadwir, Tufailiyin, Akblak Muluk, Kitab al-Fataya, Manakib Jund Kbilafa wa Fadbilah at-Turk, Hasid wa Mabsud, Kitab Radd ala Yabud, Sarba' wa Hajna', Saudan wa Bhaidan, Ma'ad wa Ma'ash, Kitab an-Niza', Taswiyah baina Arab wa Ajam, Sulthan wa Akblak Ablibi, al-Waid, alBuldan, Dalalah ala Anna Imamah Fardhu, Istithaah wa Khalku Af'al, Mukinin wa Ghina wa Sina'ah, Hidaya, Manbul, Akbwan, Radd ala man Hadda fi Kitabillah, Kitab Asyik, Nasyi' Mutalasyi, Hanut, Atar, Tamsil, Fadblu Ilm, Mizah wa Jidd, Jambarab Muluk, Shawalijah, Zamm Zina, Tafkir wa I'tibar, Hujjah wa Nubuwah Ila Ibrabim, Ihalah Kudrah ala Nizam, Umahat wa Aulad, I'tizal wa Fabdlubu, Akbtar wa Maratib wa Sina'ah, Abdutsati Alim, Radd ala Mann Zaama ala Anna Insan Juz'un la Yatajaza', Abu Najm wa Jawabuhu, Tufah, Ins wa Salwah, Hazm wa Azm, Kibr alMustabsin wa Mustaqbih, Naqdbu Tbib, Anasir Adab, Tabsin Amwal, Amtsal, Fadblu Fars ala Hamlaj. ${ }^{14}$

Diantara Kitab-kitab yang utama adalah al-Bayan wa Tabyin, al-Bukbala dan Kitab Hayawan. Mengenai al-Jahiz Ibnu Khaldun pernah berkata: Dasar landasan ilmu bahasa terdapat pada empat buku; Adabul Kitab karya Ibnu Kitaibah, Kitab al-Kamil karya al-Mubarad, Kitab Bayan wa Tabyin karya al-Jahiz dan Kitab an-Nawadir karya Abu Ali al-Kali, sedangkan selain empat buku ini maka merupakan cabang atau mengikuti keempat kitab tersebut.

\section{Penyimpangan Wicara}

Wicara atau an-nutqu dalam Mu'jamar-Ra'id bermakna berbicara dengan suara dan huruf yang memiliki makna. Sedangkan dalam al-Wasit bermakna berbicara. Perwujudan suara dalam lafal, dan lafal tersusun dari sekumpulan silabel, dan setiap silabel tersusun dari sekumpulan huruf, dan setiap huruf merupakan bunyi. Menurut al-Jahiz suara merupakan alat lafal dan substansi yang dengannya dihasilkan produksi dan tidak akan pernah gerakan lidah menjadi kata atau perkataan yang tersusun atau dikeluarkan tanpa adanya bunyi, dan huruf tidak dapat menjadi perkataan kecuali dengan didahului oleh proses 
perangkaian dari silabel-silabel. ${ }^{15}$ Seluruh perkatan dapat diproduksi disebabkan oleh adanya gerakan lisan yang bergerak tertentu pada lokasi artikulasi tertentu, lafal yang dihasilkan akan berbatas dengan gerakan lisan dan alat artikulasi.

Patologi bahasa merupakan cabang ilmu yang melihat dan mengkaji gangguan wicara dan strategi untuk mengatasinya. Bila dianalisa lebih lanjut terdapat beberapa kata dalam bahasa Arab yang biasa digunakan untuk menggambarkan bentuk gangguan dan kekeliruan yang terdapat pada aspek wicara seseorang, seperti kata idhtirab, aib, maradh, dan afat. Al-Jahiz dalam menjelaskan gangguan bahasa pernah menggunakan kata idbtirab, afat, kbullah, namun semua lafal tersebut hakekatnya hanyalah digunakan sebagai sinonim dari kata aib dalam menggambarkan unsur kekhususan makna yang dikandung oleh kata yang tidak termaknakan secara khusus oleh kata aib.

Al-Jahiz menganalisa beberapa bentuk gangguan atau yang ia istilahkan dengan aib. Bentuk pertama adalah lusgah. Dalam al-wasith kata lusghab diartikan dengan perubahan pengucapan lidah dari satu huruf ke huruf lain, seperti merubah huruf $t$ sin menjadi tsa', atau huruf ra' menjadi ghin. Sedangkan dalam ra'id dimaknai sesuatu yang berat untuk diucapkan oleh lidah. Al-Jahiz sendiri tidak memberikan pengertian kata ini, tetapi dari penjelasanya lebih lanjut dapat dipahami bahwa yang ia maksudkan adalah perubahan pengucapan huruf dari satu huruf ke huruf yang lain.

Al-Jahiz menyorot empat huruf yang ia masukkan kedalam kategori huruf lusghah, huruf-huruf tersebut qaf, sin, lam, dan ra. Lusgah pada huruf sin merubahnya menjadi sa, huruf qof menjadi ta, huruf lam menjadi ya dan huruf $r a$ menjadi huruf $y$ a, gain, zal, za. ${ }^{16}$

Perubahan Pengucapan Huruf Lusghah

\begin{tabular}{|c|c|c|}
\hline قلت له---->طلت له & b & ق \\
\hline بسم الله ----> بثم الله & $ث$ & س \\
\hline جمل---->جمى & ي & \multirow{2}{*}{ ل } \\
\hline ما العلة---->مكعكة & ك & \\
\hline مغة---->مرة & $\dot{\varepsilon}$ & \multirow{4}{*}{ J } \\
\hline مرة---->>مذة & ذ & \\
\hline مرة---->مظة & ظ & \\
\hline عمرو---->عمي & ي & \\
\hline
\end{tabular}

Tabel. 1

${ }^{15}$ Al-Jahiz, Al Bayan wa Tabyin,(Beirut: Darul Maktabah Hilal, 1423), hal. 12.

${ }^{16}$ Ibid., hal. 34 
Apabila dilihat lebih lanjut, teori mengenai produksi ujaran diproses melalui tiga tahap; tahap konseptualisasi, tahap formulasi dan tahap artikulasi. ${ }^{17}$ Sorotan al-Jahiz pada lusghah merupakan wilayah kajian konsep dan formulasi yang mengalami kegagalan dalam proses artikulasi. Kata sesungguhnya tidak selamanya tersimpan secara utuh dalam mentallexicon seseorang tetapi dapat mengalami pembuyaran sehingga untuk mengartikulasikan suatu kata diperlukan kerja untuk merangkai fonem-fonem yang terpisah-pisah hingga diproduksi menjadi bunyi.

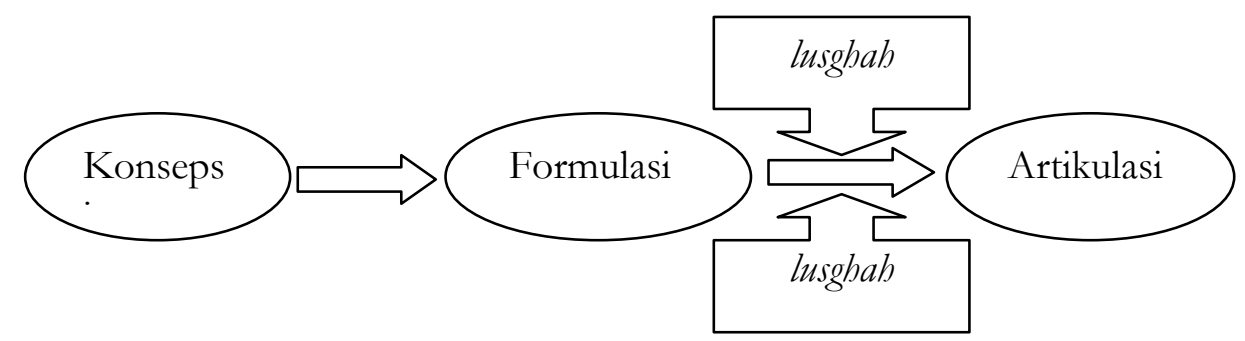

Bagan 1. lusghah dalam produksi bahasa

Yang terjadi pada lusghah merupakan kekeliruan asembling atau kekeliruan bentuk kata yang dipilih telah benar tetapi pengucapannya keliru. Kekeliruan pada posisi bunyi mengalami perubahan dinamakan dengan antisipasi. Pada kejadian antisipasi seseorang menggunakan suatu huruf pada posisi yang tidak seharusnya, ia mengantisipasi bunyi yang muncul seharusnya sehingga tidak muncul dengan bunyi yang tidak seharusnya. ${ }^{18}$

Al-Jahiz tidak memberikan makna khusus mengenai lusghah seakan ingin memberikan penekanan bahwa lusgah merupakan suatu fenomena gangguan yang muncul dari seseorang diluar kesadaran dan tanpa tujuan untuk memberikan pemaknaan yang berbeda dari kata, hanya saja apabila lusghah tersebut mengakibatkan munculnya kata lain yang memiliki makna berbeda akan dapat memunculkan kesalahpahaman dari pendengar.

Lusghah dapat juga terjadi pada seseorang yang mengalami afasia yang merupakan penyakit wicara yang menyebabkan seseorang tidak dapat berbicara dengan baik karena adanya penyakit tersebut pada otak. Penyakit ini terjadi karena orang tersebut menderita stroke atau penyempitan pembuluh darah ke otak sehingga sebagian otaknya mengalami kekurangan oksigen dan menjadi cacat. ${ }^{19}$ Pada afasia perubahan bunyi terjadi karena tidak adanya kemampuan alat wicara untuk mengartikulasikan bunyi yang diinginkan. Gangguan wicara pada orang dewasa dapat disebabkan oleh adanya penyakit yang menyerang hemisfir

${ }^{17}$ Meyer,Form Representation in Word Formation,(Whedon: 2000), hal. 49

${ }_{18}$ Dardjowidjojo,Psikolinguistik Pengantar Pemahaman Bahasa Manusia,Jakarta: Yayasan Pustaka Obor), hal. 151.

${ }^{19}$ Ibid., hal, 151. 
kiri yang mengakibatkan munculnya gangguan wicara, hal ini terjadi karena adanya penyempitan pembuluh darah atau gangguan lain yang menyebabkan jumlah oksigen didalam otak berkurang. Pada masa Al-Jahiz kajian mengenai gangguan berbahasa belum sampai pada aspek neurologi, sehingga penyebab lusghah belum dikaji secara mendalam.

Pendapat lain menyatakan bahwa bentuk gangguan dalam berbahasa dapat disebut dengan gangguan ibdaliyah, hal ini berhubungan dengan proses formulasi huruf, pengucapan dan pengartikulasiannya. ${ }^{20}$ Dalam beberapa kasus seseorang mengalami dua lusgah sekaligus, seperti yang diceritakan al-Jahiz mengenai Abdullah bin Khalid al-Umawi yang menuturkan dua lusghah huruf "lam" dan huruf " $r a "$ menjadi bunyi huruf "ýa" dalam satu waktu. Pernah ia berkata suatu waktu "مو ياي ويي" padahal yang ia ingin katakan "مولاي ولي الري".

Realitas lusgah dijelaskan al-Jahiz sebagai suatu gangguan yang tidak menunjukan kualitas kemampuan intelektual. Al-Jahiz menjelaskan bahwa pada lusghab huruf $r a$ menjadi $y a$, za dan $d z_{b o}$ tidak hanya terjadi pada kaum awam, tetapi juga ditemukan pada pembesar-pembesar, dan para ulama. ${ }^{22}$ Pada perkembangan studi patologi modern, mereka yang memiliki gangguan berbicara apabila diberikan metode yang tepat gangguan tersebut tidak memberikan pengaruh bagi perkembangan intelektual seseorang. Sebagai bukti beberapa orang yang memiliki kelainan dan gangguan dapat menunjukan kemampuan yang diluar dugaan, seperti Albert Einstein yang diduga menderita gangguan disleksia, semacam gangguan kesulitan membaca dan belajar dan sindrom asperger. Contoh lain Hee Ah Lee seorang yang menderita down syndrom yang memiliki kelebihan dalam bidang seni musik, Richard Charles Nicholas Branson pemilik grup perusahaan multinasional Virgin yang diketahui memiliki gangguan kesulitan belajar dan tidak pernah menamatkan sekolah menengahnya. Untuk di Indonesia ada Herry Darsono seseorang dengan attention deficit byperactivity disorder atau gangguan pemusatan perhatian dapat tampil dan sukses dan mampu menguasai sembilan bahasa.

Pada lusghah daerah artikulasi yang menjadi subjek terjadinya kekeliruan didasarkan pada analisa huruf seluruhnya terjadi pada huruf-huruf lisaniyab baik lisaniyah Aqsha, wustha, tarf dan hafat. Sedangkan huruf yang menjadi target ketimpangan terjadi pada huruf-huruf yang bermakhraj lisaniyah tarf, aqsha dan wustha, khaisyum.

Bentuk gangguan dalam berbahasa lain diistilahkan dengan luknah. Luknah sendiri merupakan suatu bentuk gangguan berbahasa yang kerap terjadi pada penutur yang bukan penutur asli, atau penutur asli yang lama menetap di

\footnotetext{
${ }^{20}$ Fahmi, Mustofa, Amradul Kalam,(Kairo: Darul Misr li Thobaah), hal. 34.

${ }^{21}$ Al-Jahiz, Op. Cit. Al-Bayan wa Tabyin, Juz: 1, hal.53.

${ }^{22}$ Al-Jahiz, Al-Bayan wa Tabyin, Juz: 1, op. cit., hal. 30.
} 
wilayah yang menggunakan bahasa yang berbeda. Terdapat beragam penjelasan mengenai luknah itu sendiri, dalam Ar-Ra'id luknah merupakan kelemahan dalam pengucapan atau lisan yang berat, penjelasan lain ketidakmampuan seseorang untuk fasih dalam berbahasa Arab disebabkan ada unsur non-Arab. Dalam AlWasit dijelaskan luknah merupakan kesulitan seseorang dalam menuturkan bahasa Arab disebabkan pengaruh bahasa non-Arab. Sedangkan menurut alJahiz lisan dapat dikatakan terindikasi luknah apabila masuk sebagian huruf asing dalam huruf Arab, dan kebiasaan bahasa yang lebih dikuasai masuk kedalam makhraj bahasa pertama. ${ }^{23}$ Dapat disimpulkan bahwa al-Jahiz melihat luknah sebagai suatu fenomena artikulasi bahasa ibu yang tercemari oleh bahasa asing, atau bahasa asing tertentu yang makhrajnya dimasuki unsur dari bahasa ibu. Sehingga bunyi diproduksi bukan pada makhraj yang seharusnya.

Istilah luknah dipadankan dalam bahasa Inggris dengan aksen namun masih perlu dianalisa lebih lanjut apakah luknah dalam linguistik modern termasuk speech disorder atau aksen dan perlu diketahui batasan-batasan yang membedakan antara luknah yang dapat dikatakan aksen dan luknah yang berkaitan dengan gangguan berbahasa.

Dijelaskan dalam Oxford bahwa aksen merupakan cara seseorang atau kelompok atau wilayah tertentu dalam berbicara. Aksen akan terlihat ketika seorang yang bukan penutur mempelajari dan berbicara menggunakan bahasa asing. Sedangkan pada mereka yang mempelajari bahasa yang bukan bahasa ibunya sebelum usia baligh akan dapat menghilangkan luknah sama sekali sehingga hampir menyerupai penutur asli. ${ }^{24}$ Sedangkan penutur yang telah lewat usia baligh akan lebih berkemungkinan membawa unsur makhraj dari bahasa ibu dalam bahasa yang ia pelajari. Mengingat bahwa bahasa merupakan bagian dari adat kebiasaan yang berkembang yang terkadang dituturkan oleh seseorang diluar alam sadar. Fatimah berpandangan bahwa luknah terjadi tanpa disengaja. ${ }^{25}$

Al-Jahiz menceritakan tentang Muglak seorang keturunan Khurasan yang hidup, tumbuh dan besar di lingkungan masyarakat Arab di kota Kufah, namun meskipun demikian penduduk sekitar masih dapat mengetahui bahwa ia keturunan Khurasan melalui aksen bahasa ibu yang tampak dalam produksi fonologikal. Kisah Muglak memberikan pertanyaan sejak usia berapakah ia berinteraksi dengan menggunakan bahasa Arab?, dan bagaimana aksen kufah tetap terlihat dalam bahasa Arabnya?. Dalam pemerolehan bahasa, fase setelah baligh memberikan tingkat kesulitan yang berbeda. Pembelajar yang mencoba menguasai bahasa asing pada usia 12 tahun keatas tidak dapat menguasai bahasa

${ }^{23}$ Al-Jahiz, Al-Bayan wa Tabyin, Juz: 1, op. cit., hal. 32.

${ }^{24}$ Scovel, T. (2000), A Critical Review of the Critical Period Research.Annual Review of Applied Linguistics, 20, hal.213-223.

${ }^{25}$ Fatimah, Muhammad Mahjub,Dirasat fi Ilmi Lughah,(Kairo: Darun Nahdah Arabiyah), hal. 94. 
sampai ke level aksen, dan penguasaan suatu bahasa dengan sempurna hingga kemampuan dalam morfologi dan sintaksis pembelajar dapat dikatakan sama dengan penutur bahasa asli hanya dapat diperoleh pada usia dibawah 15 tahun. ${ }^{26}$ Maka aksen otentik dalam bahasa asing hanya dapat dikuasai oleh anak-anak yang memiliki kemampuan kognitif tertentu dan dapat dilatih serta diarahkan oleh orang dewasa yang memiliki pengetahuan dan penguasaan bahasa tersebut dengan baik.

Namun sedikit berbeda ketika melihat realitas luknah Al-Jahiz melakukan analisa terhadap beberapa subjek non-Arab yang menuturkan bunyi bukan pada seharusnya, seperti Ziad bin Salma yang menuturkan bunyi huruf $\sin (\omega)$ dengan syin ( $)$ dan menuturkan huruf tho ( b ) dengan ta ( ) ). Dalam kajian penguasaan modern, persoalan ketidaktepatan pengucapan bagi non-penutur asli yang mempelajari bahasa asing diusia dewasa merupakan hal yang lumrah, perkembangan kemampuan alat artikulasi yang berhenti pada usia dini termasuk hemispir bahasa pada otak menjadikan pembelajar usia muda lebih menunjukan penguasaan terhadap pengucapan ketimbang mereka yang pelajar usia dewasa. Al-Jahiz juga memberikan sorotan pada luknah yang terdapat pada orang Arab yang tinggal di negeri non-Arab.

Kemampuan untuk penguasaan bahasa asing bergantung dengan kesiapan innate elemen yang memberikan akses pada wilayah universal grammar manusia. Pada pembelajar bahasa asing usia dewasa akses kewilayah universal grammar yang terdapat pada otak telah tertutup, ${ }^{27}$ sehingga luknah pada orang dewasa yang menggunakan bahasa yang bukan bahasa ibunya bukanlah suatu yang dianggap sebagai gangguan apalagi cacat dalam berbahasa, meskipun ia telah bertahun-tahun tinggal dan bergaul dalam masyarakat tersebut.

Kesulitan penguasaan aksen yang dalam pandangan al-Jahiz diistilahkan dengan luknah apabila terjadi bukan pada penutur asli belum tepat jika dikategorikan sebagai gangguan artikulator namun merupakan gangguan wicara yang menyangkut gangguan dalam produksi bahasa atau gangguan ekspresif. Dapat dikatakan gangguan apabila aksen tersebut terlalu tampak dalam unsur bahasa dan mengakibatkan penutur tidak dapat menyampaikan maksud yang ingin disampaikan dalam simbol bunyi yang seharusnya. Penguasaan aksen merupakan hal yang berbeda dari penguasaan terhadap unsur bahasa lain seperti nahwu ataupun saraf, maka mereka yang ingin mempelajari bahasa Arab di atas usia baligh tidak akan pernah mampu untuk menjadi penutur asli secara aksen dan fonologi. Aksen sendiri termasuk kedalam fonem suprasegmental yang

${ }^{26}$ Singleton, David, "The Critical Period Hypotesis: Some Problem”. Interlinguistica, No.17 (2007), hal. 49

${ }^{27}$ Martoharjono, Gita, Suzane Flyyn,Is There an Age Faktor in Universal Grammar?, David Singleton (ed). Clevedon: Multilingual Maters, 1995, hal. 136. 
pengamatannya tidak dapat dilakukan kecuali secara langsung oleh penutur asli yang memiliki sense of language.

Apabila melihat contoh yang disebut al-Jahiz pada Ziad bin Salma akan berbeda dengan kasus Mughlak, karena pada contoh Ziad tidak tepat untuk dikatakan sebagai aksen. Pengucapan huruf dengan huruf lain lebih mengarah ke gangguan berbahasa ekspresif yang dapat merubah makna, hal ini hampir mirip dengan lusghah, hanya saja luknah dikhususkan untuk gangguan ekspresif pada mereka yang bukan penutur Arab asli. Jika dikaji lebih lanjut luknah pada Ziad Bin Salma merupakan penyimpangan yang termasuk kedalam bentuk interferensi bahasa produktif.

Interferensi merupakan kekeliruan yang disebabkan oleh terbawanya unsur-unsur dari bahasa ibu kedalam bahasa asing. ${ }^{28}$ Hartman dan Stonk menyatakan kekeliruan dalam interferensi disebabkan oleh adanya kecenderungan membiasakan pengucapan suatu bahasa terhadap bahasa lain yang mencakup pengucapan fonem, gramatikal dan kosakata. ${ }^{29}$ Interferensi yang terjadi timbal balik disebut juga dengan interferensi sistemik, namun hal ini jarang terjadi. Kecendrungan yang terjadi adalah interferensi produktif, karena dalam penggunaan bahasa tertentu dipengaruhi oleh bahasa ibu. Untuk melihat kekeliruan tersebut dapat dilakukan dengan melacak kembali bahasa ibu penutur.

Pada contoh kasus Ziad Bin Salma, interferensi lebih berdampak negatif, karena bunyi yang tidak ada dalam bahasa Ibu Zaid Bin Salma harus tergantikan dengan bunyi bahasa yang eksis dalam language device yang berhubungan dengan grammar universal dan mempengaruhi perangkat artikulator. Akhirnya luknah merupakan masuknya sebagian fonem non-Arab pada sebagian fonem Arab dan demikian juga terjadi pada bahasa-bahasa lain.

Gangguan wicara selanjutnya yang merupakan“aib” dalam pandangan alJahiz adalah lahn (لحن). Pada Al-Wasit al-lanh bermakna al-lughah juga bermakna kesalahan dalam i'rab dan menyelisihi bentuk yang benar dalam nabwu. ${ }^{30}$ Sedangkan dalam Ar-Raid berarti kesalahan dalam i'rab dan menyelisihi bentuk yang benar. Senada dengan defenisi tersebut dalam Al-Ghani, lahn adalah membunyikan kata tetapi tidak sesuai i'rab yang tepat.

Al-Jahiz tidak memberikan defenisi al-lahn melainkan hanya mengetengahkan contoh-contohnya pada realitas bahasa. Termasuk kedalam

\footnotetext{
${ }^{28}$ Nababan, Sosiolingustik, (Jakarta: Gramedia, 1984), hlm. 76.

${ }^{29}$ Chaedar Alwasilah,Beberapa Madhab dan dikotomi Teori Linguistik,(Bandung: Angkasa, 1985), hal.131.

${ }^{30}$ Majma' Lughah Arabiyah,Mu'jam Al-Wasith, (Kairo: Maktabah Syuruk Ad-Dauliyah, 2003), hal. 820.
} 
lahn adalah kekeliruan dalam mengucapkan bunyi yang terjadi pada penutur Arab asli, seperti berikut:

Contoh lahn dalam kalimat

\begin{tabular}{|c|c|}
\hline Struktur Seharusnya & Labn \\
\hline ص وَالْقُرُرَآنِ ذِي الذِّكِكِ & ص وَالْقُرُرَآنِ ذِي النِّكِرُ \\
\hline 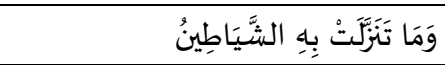 & وَمَا تَنَزَلَتَتْ بِِهِ الشَََّاطُوْنُ \\
\hline هُوَ اللَّهُ الْخَالِقُقُ الْبَارِئُ المُصَصَوِّرُ & هُوَ اللَّهُ الْخَالِقُقُ الْبَارِئُ المُصَصَُّرُ \\
\hline ظَمْيَاء & ضَمْيَاء \\
\hline
\end{tabular}

Tabel. 2.

Pada contoh penyebutan kata "ظَّمَيَاء" kesalahan tersebut terus terjadi meskipun telah dilakukan koreksi pada penutur terkait penyebutan huruf "ظ” menjadi "ض”. Labn lain yang terjadi pada kekeliruan dalam pembacaan ayat Alquran perlu dianalisa lebih lanjut, apakah kekeliruan tersebut disebabkan kekeliruan yang berkaitan dengan kilir lidah pada fitur distingtif atau kekeliruan yang memang permanen pada setiap kata yang berpola "فعلة". Lebih lanjut perlu juga diperjelas apakah kekeliruan terjadi pada konteks kalimat terbatas saja atau terjadi pada setiap kalimat. Akan terlalu cepat bila menarik kesimpulan jika menetapkan bentuk baku lahn melalui contoh yang belum dikaji berulang pada konteks kalimat berbeda.

Kekeliruan lain yaitu ketidakmampuan untuk mengucapkan beberapa kalimat tertentu. Al-Jahiz memberikan contoh penduduk kota Makki yang tidak dapat mengucapkan kata tertentu seperti kata "شانمثنا" Kekeliruan suku kata bisa saja terjadi karena kata tersebut terasa berat untuk diucapkan bagi beberapa penutur disebabkan struktur kata yang tidak biasa sehingga sulit untuk menggabungkan beberapa fonem yang memiliki artikulasi yang berdekatan.

Contoh lain yang menurut Al-Jahiz termasuk labn adalah perkataan seseorang: "هذا أحمر من هذا", sedangkan maksud sesungguhnya ia ingin mengatakan"ini lebih merah dari ini". 32 Kekeliruan seperti ini dalam linguistik modern merupakan kekeliruan yang diistilahkan dengan "Freudian Slips". Kekeliruan ini berangkat dari asumsi bahwa manusia memiliki perbendaharaan kata didalam otak atau mental leksikon, dan setiap kata memiliki medan makna atau semantic field, kata-kata yang berdekatan dapat tersimpan dalam pola cobweb dan atomic globule berdasarkan pola tertentu, kekeliruan terjadi saat kata yang ingin diucapkan tidak terproses malah yang terucap adalah kata yang berdekatan makna dan maksud. Kekeliruan seperti ini dapat juga diistilahkan dengan

31 Al-Jahiz, Al-Bayan wa Tabyin, Juz: 1, op. cit., hal. 168.

32 Al-Jahiz, Al-Bayan wa Tabyin, Juz: 1, op. cit., hal. 168. 
kekeliruan seleksi semantik, kekeliruan terjadi pada kata yang utuh dan berasal dari medan makna yang sama.

Bentuk kekeliruan selanjutnya yaitu kesalahan dalam i'rab, menurut AlJahiz kesalahan pada i'rab termasuk kekeliruan yang paling buruk dari lahn-lahn yang lain. Abdul Malik bin Marwan berkata "labn merupakan suatu aib bagi orang yang mulia." ${ }^{33}$ I'rab sendiri merupakan rambu dari rambu-rambu dalam bahasa Arab dan salah satu keunggulannya yang membedakan dari bahasabahasa lain.

Macam Lahn yang lain ialah kekeliruan dalam menggunakan kata yang tepat untuk makna yang diinginkan. ${ }^{34}$ Menurut Al-Jahiz fenomena ini termasuk bagian dari lahn. Dalam berbicara setiap pembicara menginginkan adanya keselarasan pada kata yang digunakan dan makna yang ingin disampaikan, dan kekeliruan dalam memilih kata yang tepat berujung pada salah paham dan gagalnya proses sampainya makna yang diinginkan. Kekeliruan ini berkaitan dengan faktor retrival kata, kekeliruan otak dalam memanggil kata yang tepat untuk makna yang diinginkan. Kata-kata akan tepat digunakan apabila kata tersebut sering dipakai.

Penyebab lain dapat pula disebabkan kerusakan pada area Broca pada otak yang berlanjut pada afasia motorik, sehingga terjadi gangguan pada produksi bahasa. Afasia Broca dengan merupakan sindrom yang ditandai dengan kesulitan dalam memproduksi ujaran, gangguan menentukan nada bahasa dan artikulasi, penentuan semantik, paraphasia fonemik, produksi kalimat singkat, dan tidak normalnya struktur gramatikal.

Namun labn dapat juga terjadi lebih disebabkan hal yang sederhana seperti kurangnya pengetahuan akan tatabahasa suatu bahasa, atau kurangnya loyalitas terhadap tata bahasa.

Lahn Kata-Makna

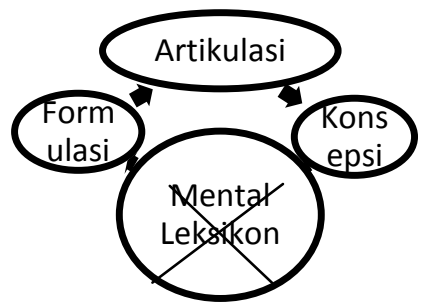

Bagan. 2

Selain gangguan dan kekeliruan tersebut, gagap juga bagian yang termasuk kedalam gangguan yang berlanjut pada kegagalan dalam menyampaikan pesan yang diinginkan. Menurut Al-Jahiz " termasuk perkara

${ }^{33}$ Al-Jahiz, Al-Bayan wa Tabyin,Juz: 2, op. cit., hal. 148.

${ }^{34}$ Al-Jahiz, Al-Bayan wa Tabyin,Juz: 2, op. cit., hal. 148. 
yang tercela dalam pembicaraan..$^{35}$ Dalam sorotan linguistik modern, gagap merupakan gangguan psikogenik, gangguan berbicara yang sering tersendatsendat, mendadak berhenti dan kalimat atau kata yang tidak terselesaikan, pada wilayah ini Al-Jahiz tidak memberikan pandangan yang luas, namun al-'Ay merupakan persoalan gangguan yang perlu penanganan lebih awal.

Gangguan gagap menjangkiti 1\% dari populasi dunia. ${ }^{36}$ Saat ini penelitian mengenai hal ini telah berkembang pesat, meskipun belum ditemukan faktor utama yang menyebabkan gagap, kecuali beberapa asumsi bahwa gagap disebabkan oleh faktor genetik dan neurofisiologi, namun terapi untuk mengatasi gangguan ini telah menunjukan kemajuan yang menggembirakan.

Gangguan-gangguan yang disebutkan oleh Al-Jahiz, baik gangguan berbicara ataupun gangguan berbahasa merupakan hal-hal yang masih terus dikaji dan dikembangkan untuk menemukan metode yang berefek baik dalam mengatasi gangguan-gangguan tersebut, Al-Jahiz memberikan gambarangambaran mengenai gangguan yang kerap terjadi pada pengguna bahasa Arab. Dalam psikolinguistik, pengetahuan tentang aspek-aspek kesulitan, kekhasan dari bahasa asing yang diajarkan menjadi penting untuk memberikan gambaran kepada pendidik mengenai alasan kenapa seorang pembelajar bahasa Arab kerap mengalami kendala dalam beberapa faktor.

\section{Penutup}

Al-Jahiz memberikan beberapa bentuk kekeliruan yang sampai hari ini masih kita temukan dalam kehidupan berbahasa manusia. Lusghah yang dalam pandangannya merupakan kekeliruan yang terjadi pada seseorang tanpa motif, dan penutur berada dalam kondisi yang tidak dapat ia hindari. Penutur yang terdapat lusghah pada bahasanya tidak mencerminkan kemampuan intelektualitasnya, namun lebih kepada persoalan kemampuan artikulator device untuk memproduksi bunyi tertentu. Pemikiran ini relevan dengan pandangan linguistik modern. Namun dalam temuan kata-kata yang kerap terindikasi lusghah diperlukan pengembangan dan kajian lebih lanjut.

Pada luknah Al-Jahiz masih belum membatasi antara aksen dan interferensi, namun ide Al-Jahiz mengenai interferensi reseptif perlu dilakukan perluasan dalam bukti empiris. Sedangkan pada lahn kesimpulan yang menarik bahwa Al-Jahiz memberikan asumsi bahwa pada gangguan labn tidak hanya disebabkan oleh faktor artikulator dan afasia motorik tetapi dapat juga didorong oleh faktor personal untuk mengganti bunyi yang terasa sulit diucapkan dengan bunyi yang ringan. Sedangkan dalam $A l-A y$ apa yang disebutkan Al-Jahiz masih

\footnotetext{
${ }^{35}$ Al-Jahiz, Al-Bayan wa Tabyin. Juz: 1, op. cit., hal. 4.

${ }^{36}$ Carlson, N. Human Communication on Physiology of Behavior. Boston: Allyn and Bacon, 2013., hal. 498
} 
sangat sederhana, pandangannya terkesan mengadili dari memberikan realitas empiris dalam fenomena tersebut.

Batasan-batasan gangguan yang Al-Jahiz sebutkan secara umum lebih tampak sebagai language disorder daripada speech disorder, sehingga dalam pembelajaran bahasa, bentuk-bentuk gangguan tersebut dapat dijadikan sebagai referensi dalam menghadapi beberapa persoalan-persoalan yang dihadapi oleh pembelajar ataupun pendidik.

\section{Bibliografi}

Aisyah, Muhammad Utsman. Dauru Jahiz, fi Darsi Sauthi Arabi. Jurnal Dirasat Ulum Insaniyah wa Islamiyah. Vol. 2 (2016).

Al-Jahiz. Al Bayan wa Tabyin. Beirut: Darul Maktabah Hilal, 1423.

Aqtas, Abdul hamid. Haula Hakikat Fushah. Jurnal Saqafiyah. Vol. 5 (2007)

Carlson, N. Human Communication on Physiology of Behavior. Boston: Allyn and Bacon, 2013.

Chaedar Alwasilah. Beberapa Madhab dan dikotomi Teori Linguistik. Bandung: Angkasa, 1985.

Dardjowidjojo. Psikolinguistik Pengantar Pemahaman Bahasa Manusia. Jakarta: Yayasan Pustaka Obor, 2016.

Fahmi, Mustofa. Amradul Kalam. Kairo: Darul Misr li Thobaah, 1980.

Fatimah, Muhammad Mahjub. Dirasat fi Ilmi Lughah. Kairo: Darun Nahdah Arabiyah, T'T.

Hamawi, Yakut. Mu'jam Adabi Juz 12. Kairo: Maktabah Hindiyah, 1926.

J.R. Kantor. Human Personality and Its Pathology. The Journal of Philosophy, Psychology and Scientific Methods, Vol. 16, No. 9 (Apr.24, 1919).

Jum'ah, Rahim. Dars Shauti wa Sharfi inda Jahiæ. Jurnal Kuliyah Tarbiyah Asasiyah. Vol. 2 (2008)

Majma' Lughah Arabiyah. Mu'jam Al-Wasith.Kairo: Maktabah Syuruk AdDauliyah, 2003

Mas’ud, J. Ar-Ra’id Mujam Lughawi Ashri. Beirut: Darul Ilmi Lil Alamin, 1992.

Martoharjono, Gita, Suzane Flyyn. Is There an Age Faktor in Universal Grammar?, David Singleton (ed). Clevedon: Multilingual Maters, 1995

Meyer. Form Representation in Word Formation. Whedon, 2000.

Miolo, G, Devora, S. Speech-Language Pathology and Education Students Engage in Interprofessional Collaborative Practice to Support Children with Special Needs in 
Preschool Settings. Journal of Interprofessional Education \& Practice. Vol. 4 (2016).

Murtadha, Ibnu. Tabaqat Mu'tąilah. Beirut: Maktabah Katulikiyah, 1961.

Nababan, Sosiolingustik. Jakarta: Gramedia, 1984.

Roth Froma, Collen, Worthington. Treatment Resource Manual (For Speech- Language Pathology). USA: Delmar, 2011.

Scovel, T. A Critical Review of the Critical Period Research.Annual Review of Applied Linguistics.(2000)

Singleton, David. "The Critical Period Hypothesis: Some Problem". Interlinguistica, No.17 (2007)

Tim Pusat Bahasa. Kamus Besar Bahasa Indonesia. Jakarta: Pusat Bahasa, 2008.

Umar, Ahmad Mukhtar. Dirasat Sautiyah wa Ta'limal-Lughah Arabiyah lil Ajanib. Madinah: Maktabah Arabiyah, 1401.

Verhoeven, Balkom. Classification of developmental language disorders: theoretical issues and clinical implications. New Jersey: Lawrence Erlbaum Associates, Inc, 2004. 